\title{
Smoke in the Great Plains, USA: an increasing phenomenon with potential policy and health implications
}

\author{
Heath D. Starns ${ }^{1 *}$ D, Douglas R. Tolleson ${ }^{1}$, Robert J. Agnew², Elijah G. Schnitzler ${ }^{3}$ and John R. Weir ${ }^{4}$
}

\begin{abstract}
In recent decades, as wildland fire occurrence has increased in the United States, concern about the emissions produced by wildland fires has increased as well. This growing concern is evidenced by an increase in scientific articles investigating effects of wildland smoke on public health, and ongoing research projects assessing wildland smoke hazards. We reviewed primary literature evaluating wildland smoke in the United States and determined that the vast majority of available literature addresses the northwestern and southeastern US. We discovered that a significant knowledge gap exists for the Great Plains, a region where wildfire and prescribed fire occur frequently. In this region, wildfire and prescribed fire are important economically, ecologically, and culturally. Given the paucity of data regarding emissions from Great Plains fuels and the increase in fire occurrence in the region, we suggest that more active research is needed to fill this gap.
\end{abstract}

Keywords: air quality, biomass burning, carbon dioxide, emissions, grasslands, ozone, prescribed fire, public health, rangelands, wildland

\section{Resumen}

En décadas recientes, como consecuencia del incremento en la ocurrencia de incendios de vegetación en los EEUU, la preocupación por las emisiones que estos incendios producen también se incrementó. Esta creciente preocupación se evidencia por el incremento de los artículos científicos que investigan los efectos del humo proveniente de estos incendios en la salud pública y otros proyectos en marcha para determinar los peligros potenciales de estos humos. Revisamos la literatura primaria que evalúa el humo proveniente de incendios de vegetación en los EEUU, y determinamos que la vasta mayoría de la literatura disponible aborda el noroeste y sureste de los EEUU. Descubrimos que una gran falta de conocimiento existe para las Grandes Planicies centrales de EEUU, donde tanto los incendios naturales como las quemas prescriptas ocurren frecuentemente. En esta región, tanto los incendios naturales como las quemas prescriptas son económica, ecológica, y culturalmente importantes. Dada la escasez de datos relacionados con las emisiones por combustibles vegetales en las Grandes Planicies y el incremento en la ocurrencia de incendios en esta región, sugerimos la necesidad de activar las investigaciones para llenar este vacío de información.

\footnotetext{
* Correspondence: Heath.Starns@ag.tamu.edu

${ }^{1}$ Texas A\&M AgriLife Research, P.O. Box 918, Sonora, Texas 76950, USA

Full list of author information is available at the end of the article
}

\section{Springer Open}

(c) The Author(s). 2020 Open Access This article is licensed under a Creative Commons Attribution 4.0 International License, which permits use, sharing, adaptation, distribution and reproduction in any medium or format, as long as you give appropriate credit to the original author(s) and the source, provide a link to the Creative Commons licence, and indicate if changes were made. The images or other third party material in this article are included in the article's Creative Commons licence, unless indicated otherwise in a credit line to the material. If material is not included in the article's Creative Commons licence and your intended use is not permitted by statutory regulation or exceeds the permitted use, you will need to obtain permission directly from the copyright holder. To view a copy of this licence, visit http://creativecommons.org/licenses/by/4.0/. 


\section{Introduction}

Fire is an evolutionary driver of rangelands worldwide and is essential to the persistence of many terrestrial ecosystems (Wright and Bailey 1982; Axelrod 1985; Bond et al. 2005). Human alteration of fire regimes, particularly through fire suppression, is credited with degradation of rangelands (Archer 1989; Archer et al. 2017) and subsequent increases in fuel loading and changes in fuel structure (Twidwell et al. 2013a). Such fuel accumulations have led to an increase in wildland fire in the United States over the past four decades (Donovan et al. 2017). Recently, however, policy-makers have recognized the importance of fire as an evolutionary driver of terrestrial ecosystems and have made possible the use of wildland fire for management of fire-dependent ecosystems (National Strategy 2014). In response to this change, landscapes in the United States are increasingly being restored and managed using prescribed fire (Twidwell et al. 2013b). As a consequence of increased wildland fire (both wildfire and prescribed fire) and an increasing human population, wildland fire emissions have become a public health concern and a topic of increased research interest.

Wildfire activity has been particularly high in the western US due to fuels and climatic conditions that favor large catastrophic fires (Keeley and Syphard 2019). Large fires obviously generate large volumes of smoke, potentially affecting millions of individuals (Hyde et al. 2017). In the southeastern US, where prescribed fires are frequently used for management of forests, smoke is also a significant concern due to its potential harmful impacts on susceptible populations (Weir 2009). These concerns have precipitated new lines of research aimed at understanding smoke constituents and reducing negative effects on public health. One example of such research is the Fire and Smoke Model Evaluation Experiment (FASMEE) project, which aims to improve capabilities of smoke modeling programs based on extensive sampling of smoke from wildland fires (Prichard et al. 2019).

Public concern regarding smoke is based on multiple factors including nuisance smoke, climate change, and public health. Smoke from wildland fires can cause dangerous conditions on roadways and near airports and other travel corridors by obstructing vision (Weir 2009), but there is also considerable concern regarding the release of carbon into the atmosphere (Langmann et al. 2009) and the impacts of smoke on air quality (Hyde et al. 2017). These concerns are of particular importance to managers of public and private lands who use fire (managed wildfire and prescribed fire) as part of a land stewardship strategy, because regulations affecting smoke have potential to hinder the use of fire. Indeed, more than $40 \%$ of respondents to a national survey indicated "air quality/smoke" as one of their top three impediments to prescribed fire (Melvin 2018).

\section{Prescribed fire and wildfire in the Great Plains}

Fire managers attempt to minimize the impacts of smoke on public health by executing prescribed fires when weather conditions favor smoke dispersal and wind is predicted to carry smoke away from heavily populated areas or sites with sensitive receptors such as homes or roads (Fig. 1; Weir 2009). However, smoke incursions may still occur as a result of inaccurate forecasts or unforeseen weather changes. Furthermore, several instances of long-range transport have been observed at a continental and even intercontinental scale (Jaffe et al. 2004; Craig et al. 2015). The increasing prominence of prescribed fire as a method for restoration of rangelands in the Great Plains, USA, warrants more thorough quantification of emissions from fuels specific to the region.

In a trend similar to the western United States, the Great Plains region has experienced an increase in wildfire occurrence over the past three decades (Donovan et al. 2017), which can be attributed in part to an invasion by woody plants. Ironically, the woody plant invasion is the result of land management practices, particularly poor livestock management and direct fire suppression (Briggs et al. 2005; Archer et al. 2017). If left unchecked, this invasion may result in irreversible changes to the ecosystem and lead to alternative stable states (Twidwell et al. 2013a). Millions of hectares of rangeland in the southern Great Plains have been invaded by woody plants and may be susceptible to such transitions (USDA NRCS 2018). Prescribed fire has been identified as a possible method for restoration of encroached rangelands (Twidwell et al. 2016) and

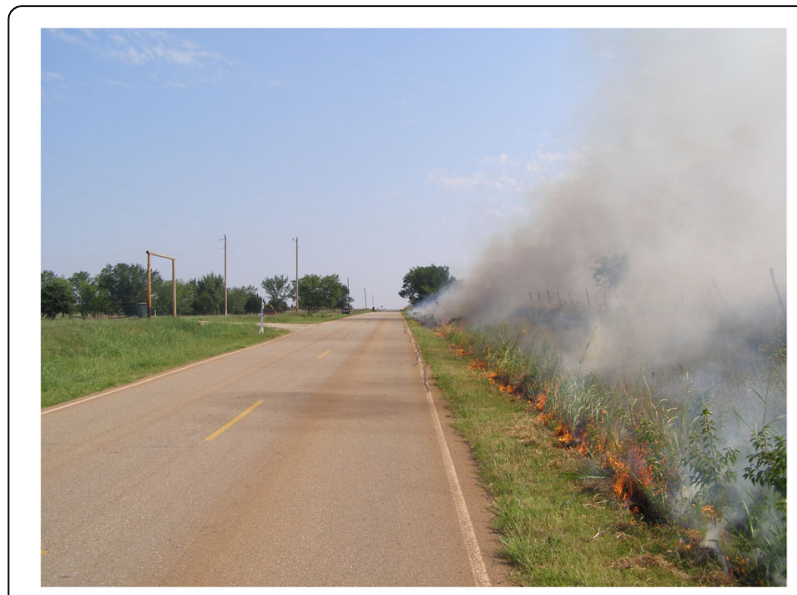

Fig. 1 Fire managers plan burns for periods when winds are favorable to direct smoke away from sensitive receptors such as roadways. Fire in Stillwater, Oklahoma, USA, on 10 August 2019. Photograph by J. Weir 
described as the most cost-effective method for improving productivity for livestock (van Liew et al. 2012). Prescribed fire combined with grazing has also been suggested as an effective method to manage the rapid growth of herbaceous biomass, thereby mitigating wildland fire behavior (Starns et al. 2019). In addition to restoration by fire, these ecosystems require frequent fire to maintain grassland structure and productivity and prevent invasion by woody plants (Fuhlendorf et al. 1996; Briggs et al. 2005; Twidwell et al. 2013b). In the southern Great Plains (states of Kansas, Oklahoma, Texas, Nebraska), more than 1 million ha were treated using prescribed fire in 2017, in addition to nearly 700000 ha affected by wildfire (Melvin 2018; NIFC 2019).

\section{Current knowledge of grassland fire emissions}

Globally, one of the most thoroughly studied biomes is the African savanna, where many landmark observations were made during pioneering work (Cofer et al. 1996; Kuhlbusch et al. 1996; Andreae et al. 1998; Hobbs et al. 2003; Trentmann et al. 2005; Keene et al. 2006). For example, emission factors of a wide range of chemical species-including those containing carbon, nitrogen, halogens, sulfur, or phosphorous (Keene et al. 2006)were measured here, providing valuable insights into the effects of grassland fires in general. Further, observations of significant mobilization of phosphorous during experimental burns (Keene et al. 2006) indicate that emissions of prescribed and wildfires can have effects on ecology in addition to air quality. More recently, burning of agricultural residues in Asia has also been investigated, including the emission of species like polycyclic aromatic hydrocarbons (PAHs) and isocyanic acid, which pose acute health risks (Singh et al. 2013; Kumar et al. 2018b). Interestingly, the total hydroxyl radical $(\mathrm{OH})$ reactivity during burning was much higher than predicted by standard atmospheric chemistry mechanisms, indicating that additional gaseous species contributing to the formation of secondary pollutants, such as ozone and secondary organic aerosol, must be incorporated into emission factors (Kumar et al. 2018a).

In North America, emissions of prescribed fire and wildfires have been studied most thoroughly for the western and southeastern US (Prichard et al. 2020), where fires commonly occur in forested areas. Comparatively few studies have reported on grass fires in North America. In the Pacific Northwest, the emissions of burning Kentucky bluegrass (Poa pratensis L.) have been measured (Dhammapala et al. 2006; Dhammapala et al. 2007a; Dhammapala et al. 2007b; Holder et al. 2017) and modeled (Jain et al. 2007; Zhou et al. 2018), largely in the context of agricultural residue burning. In the southeastern US, the emissions of prescribed fires in plots of grass and grass-shrub wildlands have also been measured (Aurell et al. 2015; Holder et al. 2016; Ottmar et al. 2016) and modeled (Hu et al. 2008), although few of the grass species are relevant to the Great Plains. Grasses in these studies were limited to wiregrass (Aristida beyrichiana Trin. \& Rupr.) and invasive Lehmann lovegrass (Eragrostis lehmanniana Nees) (Hu et al. 2008; Burling et al. 2010).

\section{Knowledge gap for the Great Plains}

In addition to the presence of unique fuel types and species in the Great Plains, many emission factors focus on the smoldering phase of combustion (Prichard et al. 2020), which is markedly shorter or absent in grassland fires (H. Starns, Texas A\&M AgriLife Research, Sonora,

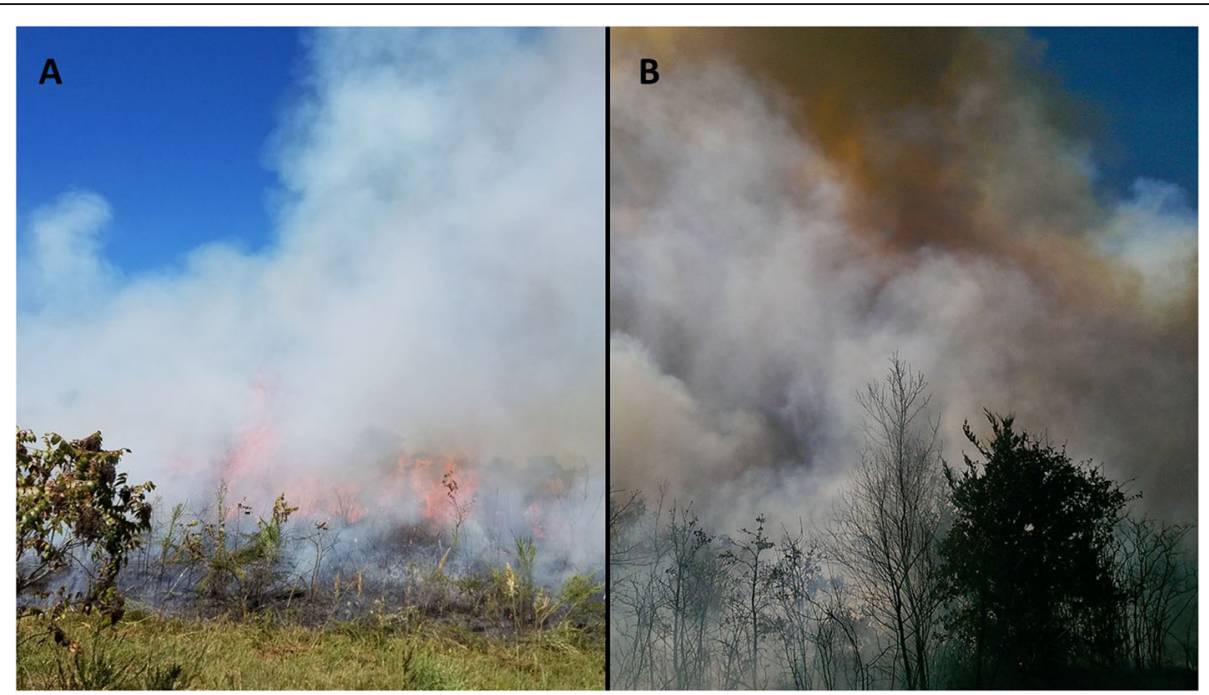

Fig. 2 Side-by-side comparison of differences in opacity of smoke between (A) grass-dominated fuels, and (B) woody-dominated fuels. Fires in Stillwater, Oklahoma, USA, on (A) 27 September 2016, and (B) 12 February 2015. Photographs by H. Starns 
Texas, USA, personal observation). In this context, local and regional air quality studies describing the effects of prescribed fires in the Great Plains have focused on modeling (Baker et al. 2016; Liu et al. 2017, 2018) using emissions factors developed outside of the Great plains. However, the recently published measurements of gaseous emissions from prescribed fires in Great Plains grasslands reported by Whitehill et al. (2019) reinforce the importance of evaluating emissions based on regional fuels. Whitehill et al. (2019) found high concentrations of emitted alkenes and oxygenated organic compounds, some of which may not have been adequately represented by previous modeling exercises in Great Plains landscapes. These pollutants may contribute significantly to secondary pollutant formation downwind, potentially leading to ozone exceedances in nearby urban areas. In fact, during April 2011, ozone exceedances occurred at air quality monitoring stations in the region due to intense seasonal prescribed burning (Craig et al. 2015). Additionally, an increase in days when the MDA8 ozone standard of $70 \mathrm{ppbv}$ is exceeded in the central region of the United States is shown to be impacted by smoke from wildfires (Brey and Fischer 2016). Furthermore, appreciable concentrations of benzene and acrolein were observed (Whitehill et al. 2019), and these join a host of other toxic species, including PAHs and isocyanic acid, previously observed to be emitted from grassland fires.

Although fires reported on by Whitehill et al. (2019) were executed in native tallgrass prairie, the plots

Table 1 Search terms used in Web of Science to determine extent of primary literature relevant to wildland fire emissions in North America (top) and the Great Plains (bottom). Terms with multiple words were entered encased in quotation marks to ensure that the phrase was treated as a single search term. Searches were performed during August 2019, with one additional record added during September 2019 due to recent publication. Prichard et al. (2020) is not included in table

\begin{tabular}{|c|c|c|c|}
\hline Area & Search term & Total results $(n)$ & Results relevant to wildland fire $(n)$ \\
\hline \multirow[t]{14}{*}{ North America } & particulate matter & 413 & 23 \\
\hline & smoke management & 4 & 1 \\
\hline & fire effluent & 0 & 0 \\
\hline & crop residue burning & 2 & 0 \\
\hline & biomass burning & 351 & 66 \\
\hline & carbonaceous aerosol & 9 & 0 \\
\hline & black carbon & 182 & 9 \\
\hline & carbon monoxide & 296 & 22 \\
\hline & smoke & 757 & 70 \\
\hline & emissions & 3050 & 121 \\
\hline & PM 2.5 & 226 & 15 \\
\hline & PM 10 & 109 & 4 \\
\hline & ozone & 1163 & 39 \\
\hline & Total & 6562 & 370 \\
\hline \multirow[t]{14}{*}{ Great Plains } & particulate matter & 22 & 0 \\
\hline & smoke management & 0 & 0 \\
\hline & fire effluent & 0 & 0 \\
\hline & crop residue burning & 2 & 0 \\
\hline & biomass burning & 14 & 0 \\
\hline & carbonaceous aerosol & 0 & 0 \\
\hline & black carbon & 20 & 0 \\
\hline & carbon monoxide & 12 & 0 \\
\hline & smoke & 32 & 1 \\
\hline & emissions & 332 & 2 \\
\hline & PM 2.5 & 1 & 0 \\
\hline & PM10 & 2 & 0 \\
\hline & ozone & 1 & 2 \\
\hline & Total & 488 & 5 \\
\hline
\end{tabular}


burned were heavily dominated by a single species, big bluestem (Andropogon gerardii Vitman). However, Great Plains grasslands are frequently composed of highly diverse grassland communities (Palmer 2007; Whitehill et al. 2019). Because fuel chemistry impacts emissions, there is a likelihood that these various fuels produce different quantities and species of emissions (Aurell et al. 2015; Whitehill et al. 2019), an assumption that is supported anecdotally by the opacity of smoke produced (Fig. 2). Moreover, there have been no attempts to compare emissions of native and introduced grasses, or between rangeland grasses and the woody species commonly targeted during restoration fires (Ottmar et al. 2016; Twidwell et al. 2016). Such comparisons are necessary to inform fire managers of the potential impacts that their smoke will have on public health, allowing them to assess risks and benefits associated with fire.

\section{Quantifying the knowledge gap}

We used 13 search terms related to wildland fire emissions in conjunction with "North America" and the same terms in conjunction with the term "Great Plains" (Table 1). Terms containing multiple words were entered into Web of Science (www.webofknowledge.com) topic searches as phrases (e.g., biomass burning). We acknowledge that our search may not have been exhaustive, and likely omitted some works relevant to our topic that used similar terms (e.g., burning biomass rather than biomass burning). Initial searches were performed during August 2019. We also included Whitehill et al. (2019) and Prichard et al. (2020), which were published after our searches but were directly relevant to our results. Some of our searches likely overlapped due to the use of multiple keywords within a given article. Indeed, when the two most recent articles were added to our initial search results, the total result numbers increased by eight due to overlapping search terms. However, we feel our searches successfully obtained unbiased samples of works done in North America and in the Great Plains, and offer a glimpse into the dearth of emissions data for the Great Plains relative to the remainder of North America.

The vast majority of our search results were related to emissions from industrial or other sources not associated with wildland fire. Of 6562 articles relating to our keywords in North America, only 370 ( 5.6\%) of those related directly to wildland fire (Table 1). However, when we narrowed our search using the term "Great Plains" rather than "North America," we found only 488 results, with only $5(\sim 1 \%)$ relevant to wildland fire within the region (Table 1). Despite the pervasive nature of fire in the Great Plains, we found only a single effort to quantify emissions from fuels common to the region (Whitehill et al. 2019).

\section{Conclusions}

Considering the geographic scale of the Great Plains and the dependence upon fire to maintain and restore grasslands within the region, emissions from Great Plains fuels are likely to become a significant driver of policy in the future. However, literature quantifying such emissions is scarce-emissions research to date has focused on forested lands in the southeast and northwest portions of the US, and shrublands in the western region (Akagi et al. 2011; Burling et al. 2011; Whitehill et al. 2019). Furthermore, the currently ongoing FASMEE project (May et al. 2014) maintains the focus on these regions. We emphasize that the FASMEE project is a well planned and much needed exploration of wildland fire emissions. Our goal in this paper is to highlight the knowledge gap that exists in the Great Plains, not to detract from other research. The fact remains that fire, and therefore smoke, will continue to occur in the Great Plains and has potential to negatively affect public health in this and other regions of the United States. As such, smoke may become an increasingly important challenge to maintaining the ecological process of fire on Great Plains rangelands. Active research into the emissions of native and introduced grass and woody fuels in this region would greatly improve our ability to manage smoke and protect the public.

\section{Authors' contributions \\ HS and JW initiated the study. HS performed the literature searches. All authors contributed to writing the manuscript. All authors read and approved the final manuscript. \\ Funding \\ None. \\ Availability of data and materials \\ Not applicable. \\ Ethics approval \\ Not applicable. \\ Consent for publication \\ Not applicable. \\ Competing interests \\ The authors declare that they have no competing interests. \\ Author details \\ ${ }^{1}$ Texas A\&M AgriLife Research, P.O. Box 918, Sonora, Texas 76950, USA. ${ }^{2}$ Fire Protection \& Safety Engineering Technology, Oklahoma State University, 545 Engineering North, Stillwater, Oklahoma 74078, USA. ${ }^{3}$ Department of Chemistry, Oklahoma State University, 107 Physical Sciences, Stillwater, Oklahoma 74078, USA. ${ }^{4}$ Department of Natural Resource Ecology \& Management, Oklahoma State University, 008C Agricultural Hall, Stillwater, Oklahoma 74078, USA.}

Received: 20 February 2020 Accepted: 22 April 2020

Published online: 18 May 2020

References

Akagi, S.K., et al. 2011. Emission factors for open and domestic biomass burning for use in atmospheric models. Atmospheric Chemistry and Physics 11: 40394072. https://doi.org/10.5194/acp-11-4039-2011. 
Andreae, M.O., et al. 1998. Airborne studies of aerosol emissions from savanna fires in southern Africa: 2. Aerosol chemical composition. Journal of Geophysical Research-Atmospheres 103: 32119-32128. https://doi.org/10.1029/ 98jd02280.

Archer, S. 1989. Have southern Texas savannas been converted to woodlands in recent history. American Naturalist 134: 545-561. https://doi.org/10.1086/ 284996.

Archer, S.R., E.M. Andersen, K.I. Predick, S. Schwinning, R.J. Steidl, and S.R. Woods 2017. Woody plant encroachment: causes and consequences. In Rangeland Systems, 25-84. New York: Springer https://doi.org/10.1007/978-3-319-467092 2. 2 .

Aurell, J., B.K. Gullett, and D. Tabor. 2015. Emissions from southeastern US Grasslands and pine savannas: Comparison of aerial and ground field measurements with laboratory burns. Atmospheric Environment 111: 170-178. https://doi.org/10.1016/j.atmosenv.2015.03.001.

Axelrod, D.I. 1985. Rise of the grassland biome, central North-America. Botanical Review 51: 163-201. https://doi.org/10.1007/bf02861083.

Baker, K.R., et al. 2016. Contribution of regional-scale fire events to ozone and PM2.5 air quality estimated by photochemical modeling approaches. Atmospheric Environment 140: 539-554. https://doi.org/10.1016/j.atmosenv. 2016.06.032.

Bond, W.J., F.I. Woodward, and G.F. Midgley. 2005. The global distribution of ecosystems in a world without fire. New Phytologist 165: 525-538 https://doi. org/10.1111/j.1469-8137.2004.01252.x.

Brey, S.J., and E.V. Fischer. 2016. Smoke in the city: how often and where does smoke impact summertime ozone in the United States? Environmental Science \& Technology 50: 1288-1294 https://doi.org/10.1021/acs.est.5b05218.

Briggs, J.M., A.K. Knapp, J.M. Blair, J.L. Heisler, G.A. Hoch, M.S. Lett, and J.K. McCarron. 2005. An ecosystem in transition. Causes and consequences of the conversion of mesic grassland to shrubland. Bioscience 55: 243-254. https:// doi.org/10.1641/0006-3568(2005)055[0243:aeitca]2.0.co;2.

Burling, I.R., et al. 2011. Airborne and ground-based measurements of the trace gases and particles emitted by prescribed fires in the United States. Atmospheric Chemistry and Physics 11: 12197-12216. https://doi.org/10.5194/ acp-11-12197-2011.

Burling, I.R., et al. 2010. Laboratory measurements of trace gas emissions from biomass burning of fuel types from the southeastern and southwestern United States. Atmospheric Chemistry and Physics 10: 11115-11130. https:// doi.org/10.5194/acp-10-11115-2010.

Cofer, W.R., J.S. Levine, E.L. Winstead, D.R. Cahoon, D.I. Sebacher, J.P. Pinto, and B. J. Stocks. 1996. Source compositions of trace gases released during African savanna fires. Journal of Geophysical Research-Atmospheres 101: 23597-23602. https://doi.org/10.1029/95jd02048

Craig, K., Y. Du, S. Reid, T. Gross, and D. Watson. 2015. Developing agricultural burning emissions inventories to support the quantification of fire-related ozone impacts for an exceptional event demonstration. In International Emission Inventory Conference, San Diego, California USA. US Environmental Protection Agency.

Dhammapala, R., C. Claiborn, J. Corkill, and B. Gullett. 2006. Particulate emissions from wheat and Kentucky bluegrass stubble burning in eastern Washington and northern Idaho. Atmospheric Environment 40: 1007-1015. https://doi.org/ 10.1016/j.atmosenv.2005.11.018.

Dhammapala, R., C. Claiborn, J. Jimenez, J. Corkill, B. Gullett, C. Simpson, and M. Paulsen. 2007a. Emission factors of PAHs, methoxyphenols, levoglucosan, elemental carbon and organic carbon from simulated wheat and Kentucky bluegrass stubble burns. Atmospheric Environment 41: 2660-2669. https://doi. org/10.1016/j.atmosenv.2006.11.023.

Dhammapala, R., C. Claiborn, C. Simpson, and J. Jimenez. 2007b. Emission factors from wheat and Kentucky bluegrass stubble burning: Comparison of field and simulated burn experiments. Atmospheric Environment 41: 1512-1520. https://doi.org/10.1016/j.atmosenv.2006.10.008.

Donovan, V.M., C.L. Wonkka, and D. Twidwell. 2017. Surging wildfire activity in a grassland biome. Geophysical Research Letters 44: 5986-5993. https://doi.org/ 10.1002/2017gl072901.

Fuhlendorf, S.D., F.E. Smeins, and W.E. Grant. 1996. Simulation of a fire-sensitive ecological threshold: A case study of Ashe juniper on the Edwards plateau of Texas, USA. Ecological Modelling 90: 245-255. https://doi.org/10.1016/03043800(95)00151-4

Hobbs, P.V., et al. 2003. Evolution of gases and particles from a savanna fire in South Africa. Journal of Geophysical Research-Atmospheres 108: 21. https://doi. org/10.1029/2002jd002352.
Holder, A.L., et al. 2017. Emissions from prescribed burning of agricultural fields in the Pacific Northwest. Atmospheric Environment 166: 22-33. https://doi.org/ 10.1016/j.atmosenv.2017.06.043.

Holder, A.L., G.S.W. Hagler, J. Aurell, M.D. Hays, and B.K. Gullett. 2016. Particulate matter and black carbon optical properties and emission factors from prescribed fires in the southeastern United States. Journal of Geophysical Research-Atmospheres 121: 3465-3483. https://doi.org/10.1002/2015jd024321.

Hu, Y.T., et al. 2008. Simulation of air quality impacts from prescribed fires on an urban area. Environmental Science \& Technology 42: 3676-3682. https://doi. org/10.1021/es071703k

Hyde, J.C., et al. 2017. Air quality policy and fire management responses addressing smoke from wildland fires in the United States and Australia. International Journal of Wildland Fire 26: 347-363. https://doi.org/10.1071/ wf16154.

Jaffe, D., et al. 2004. Long-range transport of Siberian biomass burning emissions and impact on surface ozone in western North America. Geophysical Research Letters 31: 4. https://doi.org/10.1029/2004gl020093.

Jain, R., et al. 2007. Development of the ClearSky smoke dispersion forecast system for agricultural field burning in the Pacific Northwest. Atmospheric Environment 41: 6745-6761. https://doi.org/10.1016/j.atmosenv.2007.04.058.

Keeley, J.E., and A.D. Syphard. 2019. Twenty-first century California, USA, wildfires: fuel-dominated vs. wind-dominated fires. Fire Ecology 15: 15. https://doi.org/ 10.1186/s42408-019-0041-0.

Keene, W.C., et al. 2006. Emissions of major gaseous and particulate species during experimental burns of southern African biomass. Journal of Geophysical Research-Atmospheres 111: 18. https://doi.org/10.1029/ 2005jd006319.

Kuhlbusch, T.A.J., M.O. Andreae, H. Cachier, J.G. Goldammer, J.P. Lacaux, R. Shea, and P.J. Crutzen. 1996. Black carbon formation by savanna fires: Measurements and implications for the global carbon cycle. Journal of Geophysical Research-Atmospheres 101: 23651-23665. https://doi.org/10.1029/ 95jd02199.

Kumar, A., S.L. Wu, Y.X. Huang, H. Liao, and J.O. Kaplan. 2018a. Mercury from wildfires: Global emission inventories and sensitivity to 2000-2050 global change. Atmospheric Environment 173: 6-15. https://doi.org/10.1016/j. atmosenv.2017.10.061.

Kumar, V., B.P. Chandra, and V. Sinha. 2018b. Large unexplained suite of chemically reactive compounds present in ambient air due to biomass fires. Scientific Reports 8: 15. https://doi.org/10.1038/s41598-017-19139-3.

Langmann, B., B. Duncan, C. Textor, J. Trentmann, and G.R. van der Werf. 2009. Vegetation fire emissions and their impact on air pollution and climate. Atmospheric Environment 43: 107-116. https://doi.org/10.1016/j.atmosenv. 2008.09.047.

Liu, Z.F., Y. Liu, J.P. Murphy, and R. Maghirang. 2017. Estimating Ambient Ozone Effect of Kansas Rangeland Burning with Receptor Modeling and Regression Analysis. Environments 4: 14. https://doi.org/10.3390/environments4010014.

Liu, Z.F., Y. Liu, J.P. Murphy, and R. Maghirang. 2018. Contributions of Kansas rangeland burning to ambient O-3: Analysis of data from 2001 to 2016. Science of the Total Environment 618: 1024-1031. https://doi.org/10.1016/j. scitotenv.2017.09.075.

May, A.A., et al. 2014. Aerosol emissions from prescribed fires in the United States: A synthesis of laboratory and aircraft measurements. Journal of Geophysical Research-Atmospheres 119: 11826-11849. https://doi.org/10.1002/ 2014jd021848.

Melvin M. 2018. 2018 National prescribed fire use survey report Technical Report 03-18 Coalition of Prescribed Fire Councils, Inc

National Strategy. 2014. National Cohesive Wildland Fire Management Strategy.

NIFC. 2019. National Interagency Fire Center. https://www.nifc.gov/firelnfo/ firelnfo_stats_lgFires.html. Accessed July 2019

Ottmar, R.D., et al. 2016. Measurements, datasets and preliminary results from the RxCADRE project-2008, 2011 and 2012. International Journal of Wildland Fire 25: 1-9. https://doi.org/10.1071/wf14161.

Palmer, M.W. 2007. The vascular flora of the Tallgrass Prairie Preserve, Osage County, Oklahoma. Castanea 72: 235-246. https://doi.org/10.2179/06-29.1.

Prichard, S., et al. 2019. The Fire and Smoke Model Evaluation ExperimentA Plan for Integrated, Large Fire-Atmosphere Field Campaigns. Atmosphere 10: 23. https://doi.org/10.3390/atmos10020066.

Prichard, S.J., et al. 2020. Wildland fire emission factors in North America: synthesis of existing data, measurement needs and management applications. International Journal of Wildland Fire 29: 132-147. https://doi. org/10.1071/wf19066. 
Singh, D.P., R. Gadi, T.K. Mandal, T. Saud, M. Saxena, and S.K. Sharma. 2013. Emissions estimates of PAH from biomass fuels used in rural sector of IndoGangetic Plains of India. Atmospheric Environment 68: 120-126. https://doi. org/10.1016/j.atmosenv.2012.11.042.

Starns, H.D., S.D. Fuhlendorf, R.D. Elmore, D. Twidwell, E.T. Thacker, T.J. Hovick, and B. Luttbeg. 2019. Recoupling fire and grazing reduces wildland fuel loads on rangelands. Ecosphere 10: 15. https://doi.org/10.1002/ecs2.2578.

Trentmann, J., R.J. Yokelson, P.V. Hobbs, T. Winterrath, T.J. Christian, M.O. Andreae, and S.A. Mason. 2005. An analysis of the chemical processes in the smoke plume from a savanna fire. Journal of Geophysical Research-Atmospheres 110: 20. https://doi.org/10.1029/2004jd005628.

Twidwell, D., S.D. Fuhlendorf, C.A. Taylor, and W.E. Rogers. 2013a. Refining thresholds in coupled fire-vegetation models to improve management of encroaching woody plants in grasslands. Journal of Applied Ecology 50: 603613. https://doi.org/10.1111/1365-2664.12063.

Twidwell, D., et al. 2013b. The rising Great Plains fire campaign: citizens' response to woody plant encroachment. Frontiers in Ecology and the Environment 11: E64-E71. https://doi.org/10.1890/130015.

Twidwell, D., W.E. Rogers, C.L. Wonkka, C.A. Taylor, and U.P. Kreuter. 2016. Extreme prescribed fire during drought reduces survival and density of woody resprouters. Journal of Applied Ecology 53: 1585-1596. https://doi.org/10.1111/ 1365-2664.12674

USDA NRCS. 2018. 1997 Natural Resources Inventory, Revised December 2018. van Liew, D., J.R. Conner, U.P. Kreuter, and R. Teague. 2012. An Economic Comparison of Prescribed Extreme Fire and Alternative Methods for Managing Invasive Brush Species in Texas: a Modeling Approach. The Open Agriculture Journal 6: 17-26 https://doi.org/10.2174/1874331501206010017.

Weir JR. 2009. Conducting prescribed fires: a comprehensive manual. Texas A\&M University Press,

Whitehill, A.R., I. George, R. Long, K.R. Baker, and M. Landis. 2019. Volatile Organic Compound Emissions from Prescribed Burning in Tallgrass Prairie Ecosystems. Atmosphere 10: 14. https://doi.org/10.3390/atmos10080464.

Wright HA, Bailey AW. 1982. Fire ecology: United states and southern canada. John Wiley \& Sons,

Zhou, L.X., et al. 2018. Modeling crop residue burning experiments to evaluate smoke emissions and plume transport. Science of the Total Environment 627 523-533. https://doi.org/10.1016/j.scitotenv.2018.01.237.

\section{Publisher's Note}

Springer Nature remains neutral with regard to jurisdictional claims in published maps and institutional affiliations.

\section{Submit your manuscript to a SpringerOpen ${ }^{\circ}$ journal and benefit from:}

- Convenient online submission

- Rigorous peer review

- Open access: articles freely available online

- High visibility within the field

- Retaining the copyright to your article

Submit your next manuscript at $\boldsymbol{\nabla}$ springeropen.com 